\title{
Failing to Place Confrontation: The Car as "Void" in
} Jump

\section{Kerry-Jane Wallart}

\section{(2) OpenEdition \\ 1 Journals}

Electronic version

URL: https://journals.openedition.org/ces/428

DOI: $10.4000 /$ ces. 428

ISSN: 2534-6695

\section{Publisher}

SEPC (Société d'études des pays du Commonwealth)

\section{Printed version}

Date of publication: 10 June 2019

Number of pages: $61-74$

ISSN: 2270-0633

\section{Electronic reference}

Kerry-Jane Wallart, "Failing to Place Confrontation: The Car as "Void" in Jump", Commonwealth Essays and Studies [Online], 41.2 | 2019, Online since 05 November 2019, connection on 16 July 2021. URL: http://journals.openedition.org/ces/428; DOI: https://doi.org/10.4000/ces.428

\section{(c) $($ () $\ominus$}

Commonwealth Essays and Studies is licensed under a Licence Creative Commons Attribution - Pas d'Utilisation Commerciale - Pas de Modification 4.0 International. 


\title{
Failing to Place Confrontation: The Car as "Void" in Jump
}

Whereas moments of miscommunication stud the collection Jump, this article proposes to read five such misfiring encounters between whites and non-whites, in "What Were You Dreaming?" "Comrades," "Keeping Fit," "The Moment Before the Gun Went Off," and "Spoils," through a close examination of the spatial configurations where a confrontation can happen (and fail). In all five short stories the situation of racial inequality is mediated through banal elements: the car, food/drink, and the delivering of a testimony. I will connect these elements to the unresolved opposition cast by Agamben between bios, the political life, and zoe, the biological life. I argue that in these confrontation scenes the "others" are excluded through their very inclusion, but that they are also recognized as a political presence in the privileged site of vehicles functioning in the text as correlatives of what Agamben describes as a "void" in social spaces.

\begin{abstract}
Well, you may take my word, that nine parts in ten of a man's sense or his nonsense, his successes and miscarriages in this world depend upon their motions and activity, and the different tracks and trains you put them into; so that when they are once set a-going, whether right or wrong, 'tis not a halfpenny matter - away they go cluttering like hey-go-mad; and by treading the same steps over and over again, they presently make a road of it, as plain and as smooth as a garden-walk, which, when they are once used to, the Devil himself sometimes shall not be able to drive them off it. (Sterne 3)
\end{abstract}

\section{“Inside out" - Locating Confrontation}

In an essay about Chinua Achebe's Anthills of the Savannab Nadine Gordimer quotes the following passage (in a longer version) from the 1987 novel:

How does one begin to explain the down-trodden drivers' wistful preference for a leader driving not like themselves in a battered and spluttering vehicle but differently, stylishly in a Mercedes and better still with another down-trodden person like themselves for a chauffeur? ("Writing" 72-3)

This post-Independence tale, or even fable, speaks volumes about the so-called complex of the colonized and about the role reversals of dominated and dominating. Gordimer points out here how, in novels like Achebe's, the decolonized elite is shown to have fallen into step with the British "Imperial" described by E.M. Forster in Howards End: "In the motorcar was another type whom Nature favors - the Imperial. Healthy, ever in motion, it hopes to inherit the earth" (323). ${ }^{1}$ There is no such explicit satire in Gordimer's own style (see Ball on satire in Achebe). This is perhaps because the device

1. About this passage and others in E.M. Forster's novel, as well as about an analysis of imperialism which cuts across many of the themes broached in my paper, see Jameson. For the Forsterian influence on Gordimer's early writing see Temple-Turston, 24-5, 29. 
of satire requires a perspective which is both outside and inside a given society, a procedure rendered difficult by the fluidity of borders in the collection. The present study is premised upon the fact that the short stories in Jump are not fully understandable in terms of borders, however unstable these may be declared. I argue that the choice of this particular passage in Achebe's novel derives not from Gordimer's fascination for limits between the oppressed and the oppressor, but rather from an interest in the literary possibilities offered by the spaces where their confrontation can take place - in this instance, a car. Cars are liminal spaces of a particular nature: a combination of outsideness and insideness and therefore, a negation of both; a promise of temporary and not altogether very comfortable togetherness; and a point of view which travels, and travels fast, as such modernist writers as Proust or Woolf have pondered upon and represented in their fiction.

Roads and cars have all but become a passage obligé in African literature as a site where the excesses and lacks of post-Independence nations are blatantly displayed; see Wole Soyinka's The Road (but also "Obstacle Race"), Ben Okri's The Famished Road, Ayi Kwei Armah's The Beautyful Ones Are notyet Born (but also Fragments), Niyi Osundare's "Song of the Nigerian Driver," and the "umbilical cord" (5) of the road in the opening page of Yvonne Vera's Stone Virgins. Joyce Cary's much earlier Mister Johnson was already centred upon the construction of a road and the changes it brought as well as the oppositions it revealed. ${ }^{2}$ Cars may encapsulate everything that was wrong about apartheid - such a correlation is visible with the car which is apparently "quite safe" but is in reality an "old $[\ldots]$ chassis $[\ldots]$ cracked right through" (Gordimer, Jump 173). They represented the ability for whites to move around freely while non-whites were submitted to Pass Laws; they also symbolised a white economic privilege, with the non-white population having to walk, or travel in the still omnipresent "combis." This particular instance of inequality was played on by Alex La Guma in And a Threefold Cord: "The rich automobile beams swept above the tiny chinks of malnourished light that tried to escape from the sagging shanties, like restless hope scratching at a door" (37). Cars were not owned by blacks unless they stole them, as in the "common sob story" evoked in "Spoils" (168). This is illustrated by David Goldblatt's collection of photographs entitled The Transported of KwaNdebele, first published in 1989, at a time when Nadine Gordimer was writing some of the short stories later included in Jump. ${ }^{3}$ Just like land ownership, car ownership can be seen as a marker of inequality during apartheid. ${ }^{4}$ But because they evoke a seminomadism which was "native" before the Europeans arrived in South Africa (Elphick, Barnard), cars constitute a space where, over and again, the different "races" and ethnicities find themselves thrown together, however fleetingly. The car functions as an element of zoe, the biological life where hunting for food is thus made easier ("Spoils," "The Moment Before the Gun Went Off"), and of bios, where man is granted political existence through a sharing of space (polis) and the use of language. Cars are at times hardly symbolic but in a South African context they are heavy with meaning, to say the

2. See the extensive analysis carried out in Christiane Fioupou's La Route.

3. The photographs in the volume were taken in 1983 and 1984.

4. The situation has been so modified by the end of the apartheid regime that a National Household Travel Survey was conducted in 2013 in order to chart a situation of massive congestion in some areas of the country (mostly Gauteng and the Cape Province). 
least. ${ }^{5}$ Just as much as land itself, they belonged to the white minority, with non-whites relegated to "keeping" them for others, like the old man in "Keeping Fit" who works at an underground car park (237) for a living; but they also represent the desire to end this old order of domination and oppression.

Much convincing scholarship has unpacked the ways in which Gordimer scales down the apartheid regime and uses a microcosm (home) in order to grasp the macrocosm (the nation) (see Clingman's History most notably but also Boyers). I wish to suggest that an emphasis on "home" might also betray a somewhat Eurocentric perspective; if the term is used at the end of the collection by one of the only female black voices heard in the first person, it is also clear that "home" does not indicate a place as much as an emotional and sentimental bond between wife and husband. "Home" may not be a shelter as much as a landscape, a land, a path, for those South Africans whose ancestors do not hail from Europe and its specific traditions of domesticity. It is rather unmissable how in Jump, space is organised not only around inside and outside realms, around the erection of borders, however shifting or even unstable they may be (McCann), but also around makeshift agoras where an awkward but actual dialogue can start. One case in point is the moment when Mrs. Hattie Telford, whose very last name combines language (tell) and a car (Ford), apprises the uneasy situation of her car transporting a group of young African militants:

The others got in the back, the spokesman beside her. She saw the nervous white of his eyes as he glanced at and away from her. She searched for talk to set them at ease. Questions, of course. Older people always start with questioning young ones. Did they come from Soweto? (“Comrades," Jump 92)

Written with an internal focalization on Hattie, the passage oscillates between her prejudice (visible in her question, as if a paradigmatic township, Soweto, were the only place where blacks ever lived) and her determination to move beyond racial issues, which provokes her recasting the relation as one between old and young people instead. There is much symbolism in the "spokesman" being seated beside her, and therefore on the same level, but also a physical possibility for the two characters to look "at" (rather than "away from") each other. This gaze is a promise of dialogue - not the European logos and power discourse where the "Other" is always already spoken for, but an actual discovery of what these youths may have to say about themselves and "their version of South Africa" (111, original emphasis). The scene constitutes a conjuration of the asymmetric gaze of explorers and settlers, whereby "in the centuries of European colonization, [...] travel and travel writing were (and are) about the gaze of power. It is this that helps explain how the movements of some (non-European) peoples were effectively frozen under that narrative gaze" (Khair et al. 6-7). Mrs. Telford's car contains an attempt at circumscribing the conditions for the existence of a reciprocal look. The car appears as a transitional space deconstructing the institutional place of the University, where the meeting was held, and preparing a moment of conviviality in a home - although that final moment will fall through because of linguistic inadequacies in relation to perspectival diffractions of the "real" (96). In "Comrades," the moment of together-

5. One can think for instance of how Athol Fugard's 1980 novel Tsotsi was adapted for the screen in 2006 through the inclusion of a car theft, which redirects the finding of the baby. The denunciation of the injustices provoked by the apartheid regime becomes a critique of the neo-liberal order in the "rainbow nation," which has allowed a black African middle class to emerge better to preserve the status quo, which includes the economic interests of the car industry (see Dovey). 
ness created by the car is accidental. It betrays the reader's expectations as early as the first line, where a scene of mugging was openly suggested. It is also quite transitional, and only intended as a short ride towards the bus station, where black South Africans are thought to belong. Yet, it triggers a linguistic exchange which activates confrontation between the privileged and the underprivileged.

With this article I wish to re-think the representation of space operated in Jump through the object of the car and to connect this space of makeshift communality to language. It is perhaps useful to scrutinize place not merely as a transposition between microcosm and macrocosm, the domestic and the national, but as an aporia: a space which has lost its coordinates and social function, an absence of a forum with little room left for political debate, for opposition, for contestation and dissensus - a void which is still felt, and which produces in turn "a compressing silence" ("Comrades," Jump 92). While Barrett has convincingly charted moments of miscommunication, her approach remains phenomenological as she contends that stories in Jump "reinforce the idea that true communication between people lies in emotions and bodily needs rather than in words" (151). I would suggest that true communication remains a failure but that the spaces where it could take place are charted in a number of stories in the collection. The effects of defamiliarization often produced through the various cars represented in the collection all aim, I contend, at deconstructing Eurocentric spaces of houses, farms, streets, cities, and at interrogating a perception of the land through circulation. The latter notion has been partly inspired by Clingman's discussion of Gordimer's (July's People and The Pickup) and Coetzee's novels in terms of "navigation" (Grammar 208-9) and the ways in which such issues of journeying through space are connected by Clingman "to linguistic and - most especially - syntactic structures and progressions" (208). My analysis is less focused on grammatical facts and more on phonetic derivations - how breath becomes language in the five short stories I have singled out.

\section{Cars: Displacing the Encounter (zoe-bios)}

The symbolic function of the car is at its most visible in a later novel, The Pickup, where the "colonial encounter" between Julie Summers, an upper-class white South African, and a migrant worker from the Middle East is lodged around and in Julie's car, which is repaired by a have-not threatened with expulsion who finds cars "beautiful" (9) because he does not have one. Their unlikely encounter takes place after Julie's car has broken down and she must have it fixed: he is the mechanic - not unlike the "Cape Coloured" in "What Were You Dreaming?" who is a "panel beater," his violent frustration (intimated by "beater") being thus channelled by the needs of the white section of the South African apartheid society (Jump 215). This very car was crucial enough to the plot to give the novel its name. Julie's entrapment in space, her impossible location as a South African white in a post-apartheid society, is clinched by the very first three sentences of the novel:

Clustered predators round a kill. It's a small car with a young woman inside it. The battery has failed and taxis, cars, minibuses, vans, motorcycles butt and challenge one another, reproach and curse her, a traffic mob mounting its own confusion. (The Pickup 3)

Like the African animal tales where human strengths and weaknesses are represented by species, the social body is diffracted into vehicles of various revealing kinds. Togeth- 
erness frames the passage ("clustered," "mob"); the opening strategies deployed here turn traffic issues into existential positionalities and strife. As is recalled by JanMohamed, the first conflict between whites and blacks, in July's People, was already about a car, "because it is their only means of escape and because it symbolizes the technology that has allowed whites to control blacks in South Africa" (141).

Retrospectively, the reader's attention can be drawn to the major role played by cars in more than half of the short stories in Jump. In "My Father Leaves Home," the "old car" (61) is just as evocative of the old European world as the "horse-drawn carts" and "wagons" which are "delaying cars and buses back into another century" (58). In "Some Are Born to Sweet Delight," the fact that one of Rad's friends is driving the taxi taking Vera to the airport "while the men talked in their language" (87) can be retrospectively read as a programmatic sign of the trap she has fallen into and failed to understand. In "Amnesty," the political activism of the narrator's boyfriend, his life away from her, are encapsulated by "the combi or some car [which] comes to fetch him" (254). In "Safe Houses," "Sylvie" only meets "Harry" because her car has broken down, and her blatant lack of familiarity with the system of public transportation indicates her social isolation as a white. In "What Were You Dreaming?" the trio is brought together in a car, as the Coloured man must hitchhike because he cannot own a car, even though his job is to repair them. In "The Moment Before the Gun Went Off," the car becomes a crime scene and in "Spoils," the trajectories of the rich clients and of the African guide are jumbled together in a safari-purposed station wagon. In "Comrades," Hattie Telford only meets the group of young activists because she offers to give them a lift to town, whereas she meant to go home herself (92). Here and everywhere, the car is balanced between an intimate space of wealth and general social privilege, and on the other hand, an engagement within the social sphere. Cars of various kinds are present in every single story of the collection (with the exception of "Teraloyna"). My contention is that they represent in Jump both the extreme violence and the configuration of new spaces for dialogue, including in the non "South African" stories. This symbolic focus on a means of transportation might have been suggested to the author by a short story written by Mango Tshabangu, "Thoughts in a Train," published by Staffrider in 1978 and then included by Mothobi Mutloatse in Forced Landing, Contemporary Writings. In this short text, the train carriages reserved for whites, comfortable, almost empty, and with closed windows, are contrasted with the carriages for blacks, where travellers have to squeeze in and stand in grotesque positions or even sit on the roof - an image of inequality but also of a black numerical superiority which cannot but take the train in the direction of political representation.

In three short stories ("What Were You Dreaming?" "Comrades," and "Spoils"), a confrontation actually takes place in a car, while in "Keeping Fit," the absent car (as the unnamed character runs alongside a road made for whites to drive on) is the occasion for the encounter. Caught amidst a murderous mob which transgresses the border of the township in an episode of "black on black" violence, the character finds himself in what might be likened to the camp described by Giorgio Agamben as one of the crucial elements of our post-disaster modernity, a space where "life that does not deserve to live" is relegated (Homo Sacer 136 seq.). This space is a reactivation of the "camp" seen by Agamben as the privileged site of modernity (Homo Sacer 119-80); turning the camp into a paradigm of spatialization and containment is all the more relevant in a South 
African context since the British had devised a precursor to Nazi concentration camps during the second Boer War (1899-1902), and since the building of the apartheid regime included a system of containment through the creation of Bantustans (1951, a law followed by the Bantu Self Government Act 1959).

The emphasis on the bodies present in the cramped interior, on their weight, skin, naked limbs (234-5), bodies whose concern is not to "keep fit" but to keep alive, can be in turn compared to the purely physical life of zoe, an existence denied any political dimension. Yet, the white character receives a piece of experience and is confronted for what is probably the first time with "how the other half lives." The words of the woman reach him as a sort of nourishment as he is also given a cup of tea (in a parody of colonial ceremonies?). By an unexpected inversion, he is relegated to zoe, to mere survival, while his interlocutor might be seen to reach for the sphere of bios in her delivering a testimony, even a knowledge, of the reality of social struggles in South Africa. In itself, her saving his life cannot not be read as a political act of "keeping" the oppressor in order for him to hear what his responsibilities might be. The camp which needed to be "kept" out of sight from the point of view of drivers (230) has been sighted and turned into a site of political intervention, a polis. Alongside a road, the camp is described through a few elements whose incoherence is, I suggest, only apparent:

There were cooking pots and ashes and a tethered donkey, the scabby body of a car like the eviscerated shell of a giant beetle, lamed supermarket trolleys, mud wall, beer cans; silence. Desertion: or the vacuum created by people left behind by the passage of violence, keeping out of it, holding breath. (233)

I argue that silence and desertion, the two notions isolated by a punctuation mark at the end of the first sentence and at the beginning of the next, are at the core of the reflection proposed to the reader in Jump: moments when violence produces a nothingness which is tangible and even crucial. This passage moves beyond a tension between the inside and the outside to foreground a confusion of orders and degrees through linguistic drift. The car may or may not be a Beetle, but this type of Volkswagen - or "car of the people" - is heard behind the animal comparison; perhaps even, the "shell" evokes the formerly Anglo-Dutch oil company whose interests in the Middle East became so cardinal to the last developments of the European Empires before it became property of the "new" imperial power across the Atlantic. Likewise, the evocation of Egyptian rites of mummification ("beetle," "eviscerated") resonates phonetically with "beer"/ bier, the place where corpses are laid, a void filled by another form of emptiness. A cluster of transcultural and diachronic connotations, that "scabby body" is a void which both suggests and resists annihilation. The car becomes in "Keeping Fit" a continuum of "bits of wrecked vehicles" (231), an objective correlative for the destroyed fabric of the South African society during colonial times and apartheid, but also a space where motion could lodge itself in order to start again, if not anew.

The "eviscerated" body of a car is, I contend, a resistance to the camp, a suggestion that cars retain a connotation of motion and of change. It reverberates in the car where tourists discover the law of nature in "Spoils": "Between the beasts and the human load, the void" (173). The "void" as a space where uncertainties constitute an existential presence is working against the very grain of repeated suggestions of emptiness, epistemic and otherwise, around the African territories, as found in colonial texts - the "place of negations" denounced by Chinua Achebe, as he discusses Conrad's Heart of 
Darkness (2). The colonial discourse around a presumably absent culture is connected by Mary Louise Pratt to a "biologized body" fully aligned with Agamben's analysis of the relegation to the biological rather than the political, to zoe rather than bios, a distinction found in Aristotle (Pratt 1-12). Pratt writes the following about colonial texts and more specifically, about their representations of the Cape area:

In the midst of current scholarly critique of colonialist discourses, contemporary readers can scarcely fail to link this creation of a speechless, denuded, biologized body with the deracinated, dispossessed, disposable work force European colonialists so ruthlessly and tirelessly fought to create in their footholds abroad. One might want to argue that Sparrman's and Paterson's accounts simply reflect changes the Khoikhoi peoples themselves had undergone during the five decades of colonial intervention since Kolb. Their traditional lifeways had after all been permanently disrupted. Yet the complicity of these texts begins in the fact that they portray the African peoples not as undergoing historical changes in their lifeways, but as having no lifeways at all, as cultureless beings (sans mours, in the French version of Paterson). Whatever changes might have been taking place tend not to be expressed as changes, but are "naturalized" as absences and lacks. [...] So does the anti-conquest "underwrite" colonial appropriation, even as it rejects the rhetoric, and probably the practice, of conquest and subjugation. (53)

Drawing on the "absence" of any African culture proclaimed by colonial propaganda, Gordimer does not proceed to write back but follows the thread of such a lack, in order to project a space outside of all places. More so than houses, the car becomes as unstable, movable, dangerous, as is required by the urgency of ending the apartheid regime.

In "Keeping Fit" the scene of violence in the township can be seen as a moment of confrontation between whites and non-whites in a soon-to-be transitional South Africa: a violently physical confrontation but also a moment of testimony which upturns the direction of the "colonial encounter" where the European is always paradoxically on his or her own grounds. The border transgressed in "Keeping Fit" is not only a symbolical one between the white city and the Black township: it is a road. The transgression is not so much that of falling through the fence as of finding oneself on foot rather than in a car - and the return from that "Hell" into which the character has descended is connected to a white life spent sheltered by automobiles as he comes across a car "with men in golf caps" (239). The non-white characters have been "making him join them" (238), however briefly, in an experience of the camp, of zoe, of a denied political recognition. The fact that "the need to tell began to subside inside him" (240) as the jogger nears his home can be read as a failure of the confrontation and the exchange ends in miscommunication. Yet, some signs are ambiguous: the fact that his own family is having breakfast, and is reduced to their bodily needs; the fact that a bird is dying in a pipe just outside the house, turning it into a lethal camp; and the fact that the black father is working in an "underground" car park, which could suggest that he is surreptitiously in charge of "driving" the country within a few years. South Africa fails to offer new territories and asks to re-invent that same land of violent history and haunted underground, as is intimated in the opening paragraphs of "Once Upon a Time," where "upon" is turned into a catachresis and reactivated as a literal meaning - a place perched on a void (24). I will now examine the car in its variety of meanings, in "Comrades," "Spoils," and "What Were You Dreaming?" 


\section{Communality in a "state of exception"}

In all three stories ("Comrades," "What Were you Dreaming?" and "Spoils"), the plot revolves around the unease, but also a quest for meaning, experienced during a car journey shared by white and non-white characters. The car embodies here an ambiguity. While the Cape "Coloured" in "What Were You Dreaming?" has been expelled from his ancestral home by apartheid land evictions, his life is now governed by the line of the N1 road which runs across the country from South to North, from the Victoria and Albert Waterfront in Cape Town to the Limpopo River and the border with Zimbabwe: could the humiliation become an empowerment as well? The short story reenacts colonial narratives of exploration and delves into the "heart of the country," to borrow from Coetzee's title for his second novel (itself a re-writing of Conrad's notorious novella). Beyond contextual issues, the car's possible meaning reverberates in two directions: it could be related to the modernist aesthetics where new technologies (cars but also phones, photography or the movies ${ }^{6}$ ) might change our perception of reality. Another meaning might be approached through the notions used by McCann in her analysis of some stories in Jump (278). McCann lays the emphasis on representations of space which translate social motion, a state of flux which belies but might also corroborate the apartheid regime and the general obsession with borders which characterizes our modernity. These multi-directional signs allow meaning to proliferate, but also to err.

An emblematic device related to the colonial presence of Europeans in Africa, cars have been instrumental both to the repression of the apartheid regime, and to the struggles of the ANC. Like "Harry" himself at the end of "Safe Houses" ("There was nothing to do but keep jogging; at a traffic light the car drew up beside him and two plain-clothes men ordered him to come to the police station with them," 209) opponents were often "taken away" in the vehicles of the secret services. This is also what Teresa's husband imagines to have happened to her family ("Home," Jump 126). Nelson Mandela (dressed in a chauffeur's jacket) was arrested in a limousine thanks to a roadblock near Howick, where a monument now commemorates the event. Meanwhile, black retaliation against perceived traitors was carried out through "necklacing," with a tyre and petrol; and the ANC organization was only made possible thanks to vehicles such as the "combi" $(252,254,256)$ which symbolizes the narrator's new life of political struggle in "Amnesty." Roads have been mined in South Africa and cars blown up (by the ANC, "Spoils" 168) but also Mozambique (by ReNaMo, "Jump" 11), and this dread of white "Boer" farmers is recalled in "The Moment Before The Gun Went off"; cars have been "stoned" ("Once Upon a Time" 26) and exploded, as Mrs Telford knows her guests will do one day ("a career of wiring explosives to the undersides of vehicles," "Comrades" 96). Roads have become "strategic" "“Jump" 14) for the Mozambican counter-revolutionaries, and political refugees are careful to keep "away from the roads" ("The Ultimate Safari" 37). In the unnamed African country where the family in "A Journey" lives provisionally, the father drives to the airport in hopes of renewal which are ironically echoed by the traces left of a coup: "There were tanks rolling along

6. See the role of phones in "Home," of photography in "Jump" and "Spoils," or of movies in "Jump," "Safe Houses" or at the end of "The Ultimate Safari." 
this road not long ago, and it's unevenly patched with fresh tarmac where it was blown up" (153).

The harbingers of a sea change in the racial politics of South Africa are more often than not staged in a car. It is the case when the two wives and children of Siza are climbing into the "large station wagon" alongside the paying guests, "flesh to flesh" ("Spoils" 170). The embarkation is both awkward, with a woman talking to a black child "as if he were someone else: 'In for the kill"'; and inevitable: "It is not possible to get out" (171). This car is the occasion both of a communion ("the beating hearts in the vehicle," 172) and of the threat of overload (173), even as a new South Africa could be seen to emerge slowly, in unison and/or in competition for a limited space. The car allows the white section of the population to pretend not to see what is outside their homes, as their lifestyle includes "driv[ing] the car out of the electronically-operated gates" ("Once Upon a Time" 27) and returning home likewise. In "Spoils," the "common sob story" of the blacks' oppression goes through finding "[one's] first real bed when [one] joined a gang of car thieves" (167-8), where one finds the assimilation of the car with a home already present when Barthes was describing the Citroën Déesse, with its dashboards like a kitchen, in Mythologies (166). In this sense, my reading of these five short stories intersects some of the conclusions drawn by Rita Barnard about the mythical writing of apartheid literature, but ascribes such myth-making to the specific locus of the car.

The short story "Spoils" has a curious ending, which is and is not an epiphany. The final revelation is allowed to take place but it divides the group. The clients of the safari are let into an awesome universe of loss and gain, of humanity and animality thrown in together, and of careful distribution of what eats and what is eaten; but such a revelation is mediated through language and delivered by someone who "knows." This final scene can be compared to the kitchen in "Comrades," at the end of which the epiphany is perceived by the white character only, and expresses something the others had known before: "Only the food that fed their hunger was real" (96), where the phonetic proximity between "hunger" and "anger" can hardly be missed.

I would wonder here whether the suspension provided by epiphanies ever since their implementation by James Joyce's “The Dead" (Tigges 40-54) allows Gordimer to explore the space of an empty signification. With its phenomenological perception of reality, and its re-asserted quest for knowledge, the ending of a Gordimerian short story joins reality and impossibility, realism and the fable, the tangible object of a car and the line of flight of everything it can stand for. The accident of whites and blacks finding themselves together in a car, in "Spoils" but also "What Were You Dreaming?" and "Comrades," becomes akin to the void of "anomie," in Agamben's thinking about the state of exception (State 51-60). Neither a camp nor a shelter, a home nor a danger, space becomes that "void" of empty significations where reality can lodge itself in its barest forms. The absence of nomos is connected to sight in "What Were You Dreaming?" a story where the driving away of populations deemed undesirable by the apartheid regime ("We're talking about loading up trucks and carting black people out of sight of whites," 221) is countered by the "Cape Coloured's" presence in a car whose European driver keeps his eyes "fixed on the black faces he is trying to read" (220). A perpetual motion brings the "Other" in and out of sight, or of focus, in ways that are explicitly meta-fictional ("read"). 
At this point one might interrogate the titular clues in the collection. "Jumping" indeed suggests a suspension between spaces, a moment of life which supposes the existence of stable ground as a telos, as well as an origin. The car is an instance of the mediation operated by the state of exception between the norm (apartheid) and the reality (the individual perspective of characters who, not coincidentally, remain nameless in a large number of cases). Agamben writes:

[T] he impossible task of welding norm and reality together, and thereby constituting the normal sphere, is carried out in the form of the exception, that is to say, by presupposing their nexus. This means that in order to apply a norm it is ultimately necessary to suspend its application, to produce an exception. In every case, the state of exception marks a threshold at which logic and praxis blur with each other and a pure violence without logos claims to realize an enunciation without any real reference. (State 40)

Agamben's work on the state of exception constitutes a renewed perspective upon one of the tensions outlined by all scholarship on Gordimer between her realism and her re-working the codes of the fantastic. The difficulty linked to the realistic enterprise is not the chaos of "life," but its void; not its accumulation, but its lack. The problem is not really a prolific heterogeneity, but a homogeneity of emptiness. The methods of description are impossible after the loss of places and the disappearance of locations. There are actually no spaces other than "eviscerated" ones where an exchange can take place: a failure which in itself expresses the horrors of apartheid.

The "camp" becomes a site of brutal segregation in Jump, but that site can also be deprived of these connotations in order to start floating in suspension, a possible meeting place which redeems nothing or no one, but allows for a displacement. The "void" is no erasure but a passage where circulation can take place: "there are so many ways you don't think of, outside, when you don't need to" ("Spoils" 167). The negativity under the sign of which a space ("outside") is placed may be replaced, or not, by another positivity. In any case, the point is to move beyond the language of law, which is both fixed and final, predicated along binaries, and sufficiently vague to condemn people to living in the camp for a period which is "indeterminate," without an end but also without a definition: "he was already declared a habitual criminal, inside for an indeterminate sentence” (167, my emphases).

I will now turn to such linguistic practices as are articulated around the adjective "indeterminate," where the logocentric enunciation of the law also corresponds to a blurring of semantic meaning. It should be stated at this stage that linking a desire for a performative act of social reparation to post-Saussurian consciousness is nothing new in the field of postcolonial theory. Benedict Anderson has already developed such a reflection, and his forays into the matter are commented on in turn in a section ("Social Anonymity and Cultural Anomie") of Homi Bhabha's essay entitled "DissemiNation." Bhabha writes:

Anderson historicizes the emergence of the arbitrary sign of language - and here he is talking of the process of signification rather than the progress of narrative - as that which had to come before the narrative of the modern nation could begin. In decentring the prophetic visibility and simultaneity of medieval systems of dynastic representation, the homogeneous and horizontal community of modern society can emerge. (308)

In State of Exception, Agamben proceeds to establish a similarly paradoxical association between the (post-)modern awareness of the contingency of language, and a myth of 
origins: "everything happens as if both law and logos needed an anomic (or alogical) zone of suspension in order to ground their reference to the world of life" (60). According to this line of investigation, "the conflict seems to concern an empty space: on the one hand, anomie, juridical vacuum, and, on the other, pure being, devoid of any determination of real predicate" (ibid.) The repeated transgression of apartheid carried out in cars, where blacks and whites are able to interact and speak, or simply to breathe together, becomes the anomie whereby speech can be redirected away from propaganda and towards a presumably more accurate description of the world - through testimony.

\section{Breathing Together: Towards Speech}

In the short story entitled "Jump," the young Mozambican woman who is turned into an occasional prostitute by the main protagonist and focalizer attempts to move beyond the violence of her own commodification and suggests going to the beach. She says, "We can take a bus" (19) to the ReNaMo repentant who was promised a house and a car $(5,18)$ as tokens for his "rehabilitation" (5). This would make him part of a community whose members cannot afford a car, and it would expose him to the gaze of the people he used to fight and mutilate. Of note is the fact that she receives no answer to the offer: the bus stands here for a space of dialogue which the man will not board. In Jump, cars, buses, pick-ups and vans are sites of utterance and even of dialogue. Instead of answering, the main character "nods and leans to take a cigarette." He then is taken over by that activity, "the inhalation of the cigarette has become his breath and body" (20). The breath evokes more than one passage in "Keeping Fit" $(229,233,242)$ but also the passage in the car in "Spoils" ("the breathing mass," 172) or "Comrades" ("At the back, no one seemed even to be breathing," 92).

Breathing is just the sort of ordinary act that Gordimer derealizes and defamiliarizes, in an overall attempt at deconstructing the very routine which de facto validated apartheid on the part of the "dominating" group (see the passage in "Home" where "daily life" is plumbed as pertaining to the edifice of the apartheid regime without explicitly condoning it - "what will stop it covering up what is really happening?" 131). The most blatant example of an emphasis on breathing, the simplest form of life, appears at the beginning of "Keeping Fit" and pertains to the opening strategies. But there are others: when the youth from "Phoneng Location" (a hidden allusion to phones and the voice communication they allow?) pile into Mrs. Telford's car, "at the back, no one seemed to be breathing" ("Comrades" 92). Inherent to speech, breath is foregrounded as a presence or promise of conversation in the car. That passage towards speech is curtailed in "The Moment Before the Gun Went Off," "a moment of high excitement shared through the roof of a cab" (116) where communality is not mediated by language. The excitement corresponds to that moment when the exception is no longer included in the system, described by Agamben in "The Logic of Sovereignty" (Homo Sacer 15-29). The "familiar routine" ("The Moment" 113) is interrupted and becomes a bumpy route with a pothole on the path of the cab which will fire the gun - here also, there is a pun around the phrase "to gun the engine," which is echoed in the title and is found again in the poem by Bernat Kruger entitled "Gunning" (included in the poetry collection Never). On the contrary, "familiar" turns out to be a reliable clue, the first indication of the final revelation, a stone placed on the path of the reader who is invited to see there a catachresis, a return to the literal: the two men are, indeed, belonging to the same 
family. These reshufflings of meaning and deconstructions of logos culminate around the graveyard, where both of Lucas' parents share their grief in silence. A heterotopia of sorts, that graveyard reactivates the impossible dialogue between driver and tracker in the pick-up, it is a place beyond human activity - the opposite of an agora. Like the "wrecked vehicles" (231) in "Keeping Fit," the graveyard is turned into the vestigial trace of a former and no longer possible existence.

Yet the car's semantic function goes beyond such hermeneutic clues in the short story. The text points out to the reader its own failure at capturing the moment of Lucas' death and redirects its violence towards the roof of the cab. The title intimates a concern with what happened before while the plot is actually constituted by the aftermath of the murder, be it accidental or not. The exact moment when "The bullet pierced the roof and entered Lucas' brain by way of his throat" ("The Moment" 114) is actually replayed a few paragraphs later through a displacement of the bullet onto the aerial on the roof, functioning as a "whip":

All his vehicles, including the truck in which the black man died, have aerials that swing their whips when the driver hits a pot-hole: they are part of the security system the farmers in the district maintain, each farm in touch with every other radio, twenty-four hours out of twenty-four. (115)

The pot-hole which produces the accident (in Marais Van der Vyver's account at least) is another void whose emptiness becomes something, a mathematically "positive" value. The aerial becomes a correlative of the violence of the gun and includes the whole "system" in the guilt of the white farmer - more than the sum of its parts. The proliferation of communication means is as lethal as the rifle here, turning the cab into a space where the encounter between father and son is ended in the worst possible way by an omnipresent white discourse stronger than the a-linguistic signs exchanged by the occupants ("he hooted," 113; "Lucas thumped his fist on the cab roof three times to signal: look left," 114). The "body" of the car becomes reminiscent of the "voice in the echo-chamber of the subconscious" (23), a metaphorization of childhood stories and fairy tales, a representation of the threat of interracial and social violence, and an image, perhaps, of how language turns into mere sound when the house of fiction is not safe - which, surely, is the case with Jump and Other Stories.

In all these cases, the car becomes a metafictional representation for the text itself, as it takes its reader for a ride. Here again, Gordimer reactivates a conceit which was already traversing Coetzee's work for instance, from Magda, in In the Heart of the Country, to Slow Man, where the metafictional possibilities deployed by the open road, and the car accident, are played upon throughout.

\section{Carrelatives}

While Paul Hazell contends that the specific needs for an "Africar" (232) have not been sufficiently considered by the car industry, I would suggest that Nadine Gordimer weaves the poetics and politics of a "car-relative": a material representation of abstract notions such as postcolonial negotiations but also confrontations, recognition, guilt, and togetherness, which culminates in the secret kinship of father and son as it is revealed by their co-presence in a pickup truck. I have tried to show that a reiterated critique of white homes and black displacement represents the "archives" (Colleran) of 
apartheid but does not include the shock of the confrontation as it is staged here and there, and often in a car, in Jump - this is not to mention the fact that discussions around rootedness, African or otherwise, around a nostalgia for "home," has wreaked havoc in South Africa and elsewhere. The "carrelative" implies no idealized vision of African nomadism either, conscripting the black population into another form of seclusion and exclusion. It suggests an agora and a landscape, a chamber of echoes and the mouth from which words can start circulating (as opposed to what happens in "Home" with the fish in their "tank" (136) - another vehicle lurking and connected to silence). Not unlike the rest of the collection, the five short stories I have analysed cast a grim South African future but through its very unfolding, the text manifests the endless possibilities of metamorphosis offered by any aesthetic experience. These possibilities are not necessarily hopeful. In Gordimer's stories, characters might share Magda's awareness that "we are on the road from no A to no B" (Coetzee 21), and as previously quoted, the car is part of the "[c]ommon sob story" ("Spoils" 168) in the white progressive discourse which could be Gordimer's.

The car becomes a Bakhtinian chronotope (and Foucaldian heterochronia) where time and place mingle in a literary site of multiple interpretations; it becomes a prosaic conceit, a surprising metaphor; it is a symbol and a background, an obstacle to interpretation and an endless hermeneutic matrix. The car is, like most other elements in Gordimer's short stories, a place of failure and disillusion, an impossible setting which both launches and jeopardizes story-telling. Through aesthetic experimentations Gordimer insightfully suggests that only the restoration of places for exchanges to unfold will make way for a narrative background - and foreground. In Jump, one sees how the postcolonial trauma of land appropriation and exclusion lodges itself not in places (Sophiatown, Auschwitz, Hiroshima, the Twin Towers) but precisely in an absence of place. It is a dislocated hurt. The ethical responsibility of literature becomes an act of designating this spatial void, of circumscribing it, of thinking around its emptiness.

The "cab" in "The Moment Before the Gun Went Off" might suggest sacrificial practices, as it derives etymologically from "goat" in Latin (capra); Lucas becomes a scapegoat expelled from the "body" of the vehicle ("he [...] saw the young man fall out of the vehicle," 117). A re-enactment of the episode of Abraham and Isaac (and therefore, of Christ's martyrdom), the text tells of the absence of a redeeming transcendence at the end of the story. The rupture of teleology is highlighted by the way in which, when his son dies, the father becomes a child again, or possibly even the hunted animal ("like a dirty kid," 113) whose "white-ripple-marked flank" (114) was expressing his being the son of a white man. When the chain of generations and social bonds is made impossible in space - the very site of its impossibility being constituted by the car - language is the only element left to move on. A protean sign which asks the reader to reflect on her hermeneutic practices, the car conveys multi-directional as well as discordant meanings. The "familiar routine" of a writer who writes on a "route" whose destination is fully unknown even as she moves towards it. 


\section{Works Cited}

Achebe, Chinua. Hopes and Impediments: Selected Essays. New York: Doubleday, 1989.

Agamben, Giorgio. Homo Sacer, Sovereign Power and Bare Life. Trans. Daniel Heller-Roazen. Stanford: Stanford UP, 1998.

—. State of Exception. Trans. Kevin Attell. Chicago: The U of Chicago P, 2005.

Ball, John Clement. Satire and the Postcolonial Novel: V.S. Naipaul, Chinua Achebe, Salman Rushdie. London: Routledge, 2003.

Barnard, Alan. Hunters and Herders of South Africa. A Comparative Ethnography of the Khoisan Peoples. Cambridge: Cambridge UP, 1992.

Barnard, Rita. "The Final Safari: On Nature, Myth, and the Literature of the Emergency." Writing South Africa: Literature, Apartheid and Democracy 1970-1995. Ed. Derek Attridge and Rosemary Jolly. Cambridge: Cambridge UP, 1998. 123-40.

BarretT, Susan. "'He didn't know how to read the signs': Miscommunication in Nadine Gordimer's Jump and Other Stories." In "Nadine Gordimer, Jump and Other Stories : Parcours Critiques." Ed. Vanessa Guignery and Christian Gutleben. Special issue, Cycnos 34.3 (2018): 149-61.

Barthes, Roland. Mythologies. Paris: Seuil, 1957.

Bнавна, Homi. "DissemiNation: Time, Narrative and the Margins of the Modern Nation." Nation and Narration. Ed. Homi Bhabha. London: Routledge, 1990. 291-322.

Boyers, Robert. "Public and Private, On Burger's Daughter." Salmagundi 62 (1984): 62-92.

Cuingman, Stephen. The Novels of Nadine Gordimer: History from the Inside. London: Allen, 1986.

—. "Village, Empire, Desert: J.M. Coetzee and Nadine Gordimer." The Grammar of Identity: Transnational Fiction and the Nature of the Boundary. Oxford: Oxford UP, 2009. 205-39.

Coetzee, J.M. In the Heart of the Country. 1976. London: Vintage, 2004.

Colleran, Jeanne. "Archive of Apartheid: Nadine Gordimer's Short Fiction at the End of the Interregnum." The Later Fiction of Nadine Gordimer. Ed. Bruce King. New York: Macmillan, 1993. 237-45.

Dovey, Lindiwe. "Redeeming Features: from Tsotsi (1980) to Tsotsi (2006)." Journal of African Cultural Studies 19.2 (Dec. 2007): 143-64.

ElPHICK, Richard. Khoi Khoi and the Founding of White South Africa. Johannesburg: Ravan P, 1985.

Fioupou, Christiane. La Route: réalité et représentation dans l'oeuvre de Wole Soyinka. Amsterdam: Rodopi, 1994.

Forster, E.M. Howards End. 1910. New York: Knopf, 1921.

GoldBLATT, David. The Transported of KwaNdebele: A South African Odyssey. New York: Aperture, Center for Documentary Studies, 1989.

Gordimer, Nadine. "Is There Nowhere Else Where We Can Meet?" The Soft Voice of the Serpent and Other Stories. New York: Simon and Schuster, 1952.

—. Jump and Other Stories. 1990. London: Bloomsbury, 1991.

-. Writing and Being. Cambridge: Harvard UP, 1995.

—. The Pickup. London: Bloomsbury, 2001.

Hazell, Paul. "A Difficult Road, Designing a Post-Colonial Car for Africa." The Routledge Companion to Design Studies. Ed. Penny Sparke and Fiona Fisher. London/New York: Routledge, 2016. 230-41.

Jameson, Fredric. "Modernism and Imperialism." Nationalism, Colonialism and Literature. Ed. Seamus Deane. Minneapolis: U of Minnesota P, 1990. 41-66.

JanMohamed, Abdul. Manichean Aesthetics: The Politics of Literature in Colonial Africa. Amherst: U of Massachusetts P, 1983.

KHAIR, Tabish, ed. Other Routes: 1500 Years of African and Asian Travel Writing. Oxford: Signal, 2006.

Kruger, Bernat. "Gunning." Never. Grahamstown: Deep South, 2008. 33.

La Guma, Alex. And a Threefold Cord. Berlin: Seven Seas, 1964.

McCann, Fiona. "Borders, Barriers and Kinopolitics in Nadine Gordimer's Jump and Other Stories (1990)." Études Anglaises 71.3 (2018): 276-92.

PRATT, Mary Louise. Imperial Eyes: Travel Writing and Transculturation. London: Routledge, 1992.

StERnE, Lawrence. The Life and Opinions of Tristram Shandy, Gentleman. 1759. London: English Library Penguin, 2012.

Thsabangu, Mango. "Thoughts in a Train." Forced Landing, Africa Soutb: Contemporary Writings. Ed. Mutloatse Mothobi. Johannesburg: Ravan P, 1980.

Tigges, Wim. Moments of Moment: Aspects of the Literary Epiphany. Amsterdam: Brill Rodopi, 1999.

VerA, Yvonne. The Stone Virgins. New York: Farrar, Straus and Giroux, 2002. 